\title{
ETHNOMEDICINAL PLANTS IN THE TREATMENT OF NEURODEGENERATIVE DISEASES: A NARRATIVE REVIEW
}

\author{
Taimoor Hassan ${ }^{1,2}$, Sana Saeed ${ }^{2}$, Mamoona Hassan ${ }^{3}$, Sidra Naseem ${ }^{2}$, Sidra Siddique ${ }^{2}$ \\ ${ }^{1}$ School of Pharmacy \& School of Medicine, Changzhou University, Jiangsu, China, ${ }^{2}$ Department of Health \\ Professional Technologies, The University of Lahore, ${ }^{3}$ Institute of Agricultural Sciences, University of the \\ Punjab, Lahore, Pakistan
}

\begin{abstract}
A plethora of diseases are associated with our nervous system. Neurodegenerative diseases include Parkinson's disease, epilepsy, Alzheimer's disease, Huntington's disease, schizophrenia and depression. Many plants are known to be beneficial against certain neurodegenerative disorders. This study provides an overview of such thirty-five plants whose part, from roots to seeds or their bio-chemicals extract are used for the treatment of multiple neurodegenerative disorders in Pakistan and beyond.
\end{abstract}

KEYWORDS: Parkinson's Disease; Epilepsy; Alzheimer's Disease; Huntington's Disease; Schizophrenia; Depression; Neurodenegerative Diseases; Ethnomedicine; Ethnomedicinal Plants; Plant Extracts.

Cite as: Hassan T, Saeed S, Hassan M, Naseem S, Siddique S. Ethnomedicinal plants in the treatment of neurodegenerative diseases: a narrative review [Review Article]. Gomal J Med Sci 2021 Jan-Mar; 19(1):35-44. https://doi.org/10.46903/gjms/19.01.958

\section{INTRODUCTION}

Human body consists of nervous system which contains sensory organs and brain. ${ }^{1}$ The brain is made up of nerve cells through which all activities of the body are regulated. ${ }^{2}$ The brain is made of one hundred trillion neurons. These neurons perform many tasks such as memory, thinking, smelling, hearing and seeing. These neurons connect all organs to the brain and function in accordance with the signals that the brain receive. ${ }^{3}$ The gradual deterioration of the neurological system is called neurodegeneration. This may occur in motor, emotional, cognitive and sensory functions owing to the age or to varied environmental variables. Acute neurodegenerative disorders can be treated, however, the chronic diseases progress over the period of time. Neurodegenerative disorders are the second biggest cause of mortality worldwide, according to the global burden of diseases. ${ }^{3}$ Every year, around 6.9 million deaths from aforementioned diseases are reported. ${ }^{1,4}$

\section{Corresponding Author:}

Dr. Taimoor Hassan

Post-graduate Scholar

School of Pharmacy \& School of Medicine

Changzhou University, Jiangsu, China

E-mail: taimoorhassan408.th@gmail.com

Date Submitted: $\quad 15-08-2020$

Date Revised: $\quad 12-10-2020$

Date Accepted:
The treatment involves related processes and maneuvers to help combat damaged neurons caused by neurodegenerative diseases. Phytochemicals have an extensive application in neuroprotection for this aim. ${ }^{5}$ Investigators across the globe are identifying bioactive phytochemicals from traditional medicines, such as the Chinese medicinal system, Korean medicinal system, Indian Ayurvedic medicinal system, and the Mediterranean medicine system. ${ }^{6}$

\section{METHODOLOGY}

This narrative review was conducted in School of Pharmacy \& School of Medicine, Changzhou University, Jiangsu, China from October 2020 to December 2020. In order to assess the ethnomedicinal properties of plants in the treatment of neurodegenerative, this narrative review analyzed all articles published for the period from 2003 to 2021 in both local and foreign journals. The main question of this paper was to analyze the ethnomedicinal properties of certain plants to treat neurodegenerative diseases. To answer this question, different keywords; Parkinson's Disease, epilepsy, Alzheimer's disease, Huntington's disease, schizophrenia, depression, neurodenegerative diseases, ethnomedicine, ethnomedicinal plants and plant extracts were separately and in combination searched in different electronic databases such as CINAHL, PubMed, Scopus, Web of Science, HEC digital library, and eMedicine. The article's inclusion criteria were based on the ethnomedicinal properties 
and applications of plants. Articles with copyright, irrelevant information and lacking the full text were excluded. A total of 143 articles were selected for this study, out of which in screening step, 68 articles after review of abstract, according to criteria and duplicates were removed. In last step, 75 articles were selected for the final analysis. The medium of language of all these articles was English.

\section{DISCUSSION}

\subsection{NEURODEGENERATIVE DISORDERS}

\subsubsection{Parkinson's Disease (PD)}

It is caused by motor neuron dysfunction. Substantia nigra is compromised in this illness. Motor neurons play a prominent role in movement of body. Because of Parkinson's disease, body segments which are involved in activities are affected. Trembling of the legs, hands, faces, arms and limbs and poor coordination ${ }^{7}$ are the main signs of PD. The prevalence of this disease is assumed to be around $20 / 100,000$ population. ${ }^{8}$

\subsubsection{Epilepsy}

The irregular occurrence of febrile episodes is defined by epilepsy. Convulsions are caused by unnecessary discharge of grey cerebral neurons. ${ }^{9}$ In epilepsy, disrupted neurotransmission of the calcium and sodium channels by excess glutamate may initiate an event flow that leads to apoptosis. Worldwide, over 51 million people experience epilepsy. ${ }^{10}$

\subsubsection{Alzheimer's Disease (AD)}

Alzheimer is named after Aloes Alzheimer, a German physician. Alzheimer is a chronic illness causing brain dysfunction. It's also a kind of dementia. ${ }^{11}$ The effect is mostly on the elderly. With time this illness progresses. It is anticipated that its increase rate in individuals aged between 65 and 74 is around 3.0 percent and in those aged 85 it is 47.2 percent. ${ }^{12}$ Astrogliosis, neurofibrillary clot, amyloid-beta plaques that lead to chronic illness are formed during AD. The symptoms of Alzheimer's include cognitive impairment, sleeplessness, disturbance, memory loss, disorientation and reduced speech function. ${ }^{12}$

\subsubsection{Huntington's Disease (HD)}

It is a chromosomal disorder-related brain disorder. This is due to the impact of chromosome 4 that leads to nerve cell alterations. ${ }^{9}$ Involuntary leg movement, bracelet and head, weakened thinking, sadness and unpleasant temperament include HD symptoms. It is prevalent mostly in persons between 30 and 40 years of age. Approximately $12 / 100,000$ people are affected. ${ }^{13}$

\subsubsection{Schizophrenia}

It is a condition in which the patient does not know what is around him or what he or she is. In this disorder, nervous system up regulates neurotransmitters including dopamine, 5- $\mathrm{HT}$, acetylcholine and nor-epinephrine. ${ }^{14}$ This disorder has two distinct types depending upon its symptoms. Negative symptoms; there are no social contacts and the emotional reactions are flattened. Positive symptoms; these symptoms comprise misunderstanding, hallucinations, behavioral disturbances and thought processes abnormalities. ${ }^{14,15}$

\subsubsection{Depression}

Depression is despair. It might vary from mild realism to agony. Both environmental and biological variables determine this state. The consequences of depression lead to decreased cortical and hippocampus, 5-HT abnormalities and HPA axis dysfunctions. ${ }^{16}$ According to the World Health Organization (WHO), over 460 million individuals suffer from depression.

\subsection{PHYTOCHEMICALS USED IN TREATMENT OF NEURODEGENERATIVE DISORDERS}

\subsubsection{Alkaloids}

Alkaloids impair the autonomous nerves which control breathing, heartbeat and blood circulation. The central nervous system is also affected by alkaloids. The serotonin activity in the brain is hampered by indole alkaloids which contain an indole carbon nitrogen ring. ${ }^{17}$ Tropane alkaloids which are extracted from Datura, directly affects central nervous system (CNS) and peripheral nervous system (PNS) of humans. ${ }^{18}$

\subsubsection{Isoprenoids}

Plants contain neuroprotective compounds such as isoprenoids which are efficacious. For instance, Valerian officinalis, a rhizome includes sesquiterpenes and valepotriates that influence inhibition of GABA uptake and binding ability of GABA (B) receptors in mice synaptosomes. Similarly, Centella Asiatica, another rhizome contains triterpenoids, a-terpinene, and $\beta$-terpinene, which are efficient to strengthen and energize neurological functions. ${ }^{19}$

\subsubsection{Polyphenols}

The secondary metabolites present in plants are polyphenols. There are more than one phenolic group linked with the benzene ring. Studies demonstrated a beneficial impact of flavanols on brain and its activities. Catechin offers protection from Parkinson's disease brain damage. Inflammation of the neurons is likewise suppressed by catechin. ${ }^{20}$

\subsubsection{Fatty acids}

The structural organization of neurons is maintained by fatty acid. ${ }^{21}$ Human and animal mental deterioration is stalled by unsaturated fatty acids. The neuroprotective action of Omega- 6 and Omega- 3 acids is high. The fatty acid composition decreases over age. Likewise, trans unsaturated fatty acids help directly to signal neurons and neuroprotection to operate. ${ }^{20}$

\subsection{SOURCES OF NEUROPROTECTIVE AGENTS}

\subsubsection{Resveratrol}

Resveratrol is an antioxidant which is present in red 
grapes. It is highly effective against ischemic injury. It also protects neurons from oxidative stress caused by nitrous oxide (NO). ${ }^{22}$ It is also effective with amyloid $\beta$-peptide for the conservation of neuronal cells.

\subsubsection{Allium and Allicin}

Allium and Allicin are organosulfur composites present in Allium sativum (garlic) and Allium cepa. Allicin and allium are useful compounds for neuroprotection, as these play role in scavenging free radicals present in neuronal cells. Allyl-containing sulfides can trigger neuroprotection-related pathways that cause mitochondrial uncoupling proteins to be initiated. ${ }^{23}$

\subsubsection{Curcumin}

In Curcuma longa, curcumin is discovered. It is used to prevent neurodegenerative age-related diseases. It also reveres stress produced by impaired hippocampal neurogenesis. The BDNF (neurotrophic factor) has also been increased. ${ }^{24}$ It also inhibits glutamate excitotoxicity in rodent cells..$^{24,25}$

\subsubsection{Sulforaphane}

The Brussels sprouts, broccoli and other Cruciferaceae members contain sulforaphane. It is an isothiocyanate. It decreases the edema of the brain and protects the retinal pigment named dopaminergic neurons against mitochondrial toxicity. ${ }^{26}$

\subsection{BIOCHEMICAL ACTIVITIES OF NEUROPRO- TECTIVE PLANTS}

In neuroprotection, several plants are employed. Chemicals from various sections of the plants can be collected, and occasionally the entire plant is utilized to extract biochemical products required for nervous system safety.

\subsubsection{Centella asiatica}

Brahmoside, isothankunoside, brahminoside, asiaticoside, and thankunoside as active ingredients are present in the Centella asiatica. ${ }^{21}$ Its leaf is intended to enhance and revitalize nerve function and memory. It is also used for preventing and restoring dementia. ${ }^{22}$ The disease inhibits beta-amyloid death, utilized in Alzheimer's disease and beta-amyloid toxicity prevention. Depression, mental weakness and epilepsy are also cured by the extract of this plant ${ }^{27}$

\subsubsection{Bacopa monniera}

This plant is usually referred to as Brahmi. It is intended to stimulate memory, relieve tension during learning and anxiety. It contains stigmastanol, bacopa saponin, betulinic acid and active bacosides. It is used for healing of damaged neurons, restoration of synaptic activity, conductive nerve impulses and kinase activity. ${ }^{28}$ It also prevents cholinergic deterioration and increases cognition in rodents. ${ }^{28,29}$

\subsubsection{Picrorhiza scrophulariiflora}

The roots of plants contain terpenoids, phenolic glycosides, terpenoids, phenylethanoid glycosides and iridoid glycosides. Its rhizome is utilized in Southeast Asia as a neuroprotective agent. Neuritis development in PC12D cells in Picrosides I and II is shown via signaling pathway reliant on cellular mitogen activated protein kinase. ${ }^{30}$

\subsubsection{Ginkgo biloba}

It is used to enhance memory by removing free radicals and improving the availability of oxygen. This product is therefore utilized to treat alpha beta nitric oxide-related toxicity and Alzheimer's disease. It contains isorhamnetin and quercetin as flavonoids, sitosterols and stigmasterol as steroids, sesquiterpene lactones ginkgolides $A, B, C, J$ \& M, sesquiterpene lactones and diterpenic lactones. ${ }^{31}$

\subsubsection{Bertholettia excels}

Its common name is Brazil Nuts. It is high in choline-based lecithin ${ }^{32}$ Choline is an acetylcholine fundamental unit. In Alzheimer's disease patients, these basic units enhance the levels of acetylcholine..$^{33}$

\subsubsection{Cyperus rotundus}

Its common name is Sedge. It includes a small quantity of essential oils such as pinene, film and terpenes. It has got Anti-AChE activity of ethanol which is extracted from sedge. Its adherents have enhanced spatial learning and memory in mouse with damaged nucleus basalis of meynert after treatment with 2 dosages of extracts. ${ }^{34}$

\subsubsection{Lavandula officinalis}

It is commonly known as lavender. Oils of these plants are used in cosmetics and aromas. Lavender juice contains linalyl acetate, geraniol, ursolic acid, borneol, linalool, luteolin flavonoids, butyric acid, flaskin, camphor and valerianic acid. ${ }^{35}$ These chemicals increase the plant impact in limbic system, which causes GABA receptors to soothe and relax. In rodents which undergo reperfusion or ischemia, lavender oil reduces neurological impairment, malondialdehyde (MDA) level, strokes, carbonyl species, and reactive oxygen species. The impact is strongly neuroprotective. ${ }^{36}$

\subsubsection{Rosmarinus officinalis}

Rosemary possesses antioxidants and anti-inflammatory chemicals. The antioxidants are carnosic acid and ferulic acid, with a higher antioxidant potential than butylated hydroxyl toluene (BHT) and butylated hydroxyl anisole (BHA).$^{31}$ It also contains the inhibitors of COX-2 oleanolic acid, carvacrol, ursolic acid and eugenol. The inhibitors of COX-2 are Alzheimer's preventative..$^{37}$

\subsubsection{Hypericum perforatum}

The flowers of this plant contain tannins, essential oils, choline, hayperpyron and hayperciyn. It affects anxiety, depression, injury and neurological conditions positively. ${ }^{37}$ The extract of this plant also contaisn quercetin and quercitrine, which are useful in free radicals scavenging. Before injecting sco- 
polamine, pretreatment with hypericum showed antioxidant action. It affects glutathione peroxidase activity, glutathione level and brain MDA. ${ }^{38}$

\subsubsection{Glycyrrhiza glabra}

Alzheimer's disease is because of neuronal loss and the development of senile plaques. These plaques include amyloid- $\beta$ peptide as their fundamental component. Glycyrrhizene is an active molecule of glycyrrhiza glabra which contains glycyrrhizene, glycyrrhetine and glycyrrhizin acid. ${ }^{34}$ This has a beneficial effect on the apoptotic death of $A \beta$ fragments in nerve cells. The root extract works for brain disorders such as dementia, Alzheimer's disease and Huntington's disease. ${ }^{39}$

\subsubsection{Melissa officinalis $L$.}

Melissa officinalis $L$. is commonly known as Lemon balm. It contains rhamnocitrin, rosmarinic acid, luteolin-7-O-glucoside, methyl carnosoates and ferulic acid. It sharpens memory and enhances patient mood. The Alzheimer's disease may be treated quite efficiently because acetylcholinesterase and its antioxidant effects can be prevented. ${ }^{40}$

\subsubsection{Curcuma longa}

This rhizome is commonly known as turmeric. It is used in cooking. It is utilized as an anti-inflammatory and antioxidant source of curcumin; that primarily treat Alzheimer's disease. It keeps the equilibrium of mind. In rats it works as antidepressant. ${ }^{41}$

\subsubsection{Matricaria recutita}

It is commonly known as chamomile. It soothes the nerves, assists with digestion, aids immune system, counteracts sleeplessness, boost the brain, dissipates fatigue, and relives anxiety. ${ }^{42}$

\subsubsection{Cassia obtusifolia}

The plant has active ingredients rubrofusarin and isorubrofusarin. It protects substantianigra and neuronal degeneration of dapaminergic models among mice who are induced by 1-methyl-4-phenyl-1,2,3,6-tetrahydropyridine (MPTP). Cassia obtusifolia supplementation in 6- OHDA pc12 driven cells mitigates cell damage and mitochondrial membrane depolarization. ${ }^{43}$

\subsubsection{Coffea Arabica}

It contains caffeine. It increases motor function, decrease apomorphine-induced rotation and reverse motor deficiency in Parkinson's disease-mice. ${ }^{44}$

\subsubsection{Panax ginseng}

Ginseng is a medicinal herb from China and Korea. This herb is highly effective against plethora of disorders such as neurodegenerative disorders, cancer, hypocholesteremia, diabetes and high blood pressure. ${ }^{51}$ It impedes nigral iron levels, reduces divalent metal transporter 1 (DMT1) expression, and increases ferroportin 1 (FP1) expression in the Parkinson's disease. ${ }^{45}$

\subsubsection{Terminalia chebula}

The active ingredients of this plant are chebulinic acid, arjungenin, chebulosides I and II, punicalagin, gallic acid and punicalagin. The mature fruit triggers sharp memory. ${ }^{54}$ The NMDA and GABA receptors are discovered to be binding with a methanol extract. However, there is no evidence of the inhibition of cholinesterase. ${ }^{46}$

\subsubsection{Clitoria ternatea}

It is commonly called as butterfly-pea, contains kaempferol-3-rutinoside (sitosterol). ${ }^{47}$ This rhizome is used as brain toner in AM. It triggers memory and intellectual abilities. ${ }^{53}$ Ethanolic rhizome extract also improves memory. This impact is attributed to higher Ach and ChAT levels. The watery extract also improves Ach level in rat's hippocampus. ${ }^{48,49}$

\subsubsection{Commiphora whighitti}

C. whighitti is also called as Guggulu. This plant contains guggulipid, which is a guggulsterone. It has a storage effect to improve memory impairments caused by scopolamine. The acetyltransferase level in the hippocampus is decreased as well. This plant is effective against dementia and memory loss..$^{50}$

\subsubsection{Convolvulus pluricaulis}

The plant is usually referred to as shahkpushpi. It contains convolidine, confoline, kaempferol and steroids.$^{51}$ It is utilized in the treatment of neurological disorders by ayurvedic specialists. ${ }^{52}$ It is also utilized to slow the process of ageing. Plant extract and milk cure scrofula, syphilis, memory loss and fever effectively. ${ }^{53}$

\subsubsection{Withania somnifera}

This plant contains withanone and withasomniferin $A$, $B, C$. Its roots are generally referred to as ashwagandha and are specifically utilized in AM for intellectual and memory increase. ${ }^{60}$ The standardized root extract helps alleviate cognitive impairment. ${ }^{54} \mathrm{Hydroalcoholic}$ extract enhances in vivo neuroprotection. It has antioxidant and inflammatory properties as well. ${ }^{59}$

\subsubsection{Commiphora mukul}

The active components of this plant include sesquiterpenoids, terpenes, cuminic aldehyde, eugenol, guggulsterone I, II, Z-and-E-guggulsterone. and ketone steroids. ${ }^{55}$ It significantly reduces brain and flip neuronal cholesterol levels and inhibits the amyloidogenic route of beta-amyloid formation, likely through action against acetylcholinesterase (AChE). ${ }^{56,61}$

\subsubsection{Crocus sativus}

This plant is commonly known as saffron. It contains $\alpha-$ and $\beta$-carotenes acids, gallic acids, picrocrocin, safranal and lycopene. ${ }^{57}$ Crocus sativus's pistil alcoholic extract is beneficial for behavioral impairments in mouse models. The disruption of hippocampal synaptic plasticity can be achieved by blocking this. ${ }^{58,59}$ Saffron suppresses the deposition, aggregation and short-term memory disorders of 
the amyloid $\beta$ of the human brain. It is used for the treatment of Alzheimer's disease. .0061 $^{0}$

\subsubsection{Celastrus paniculatus}

This plant is known as black oil tree and malkangni and is available in entire South-East Asia, especially India. It possesses active components such as diacylglycerol, triacylglycerol, sterol and monoacylglycerol. ${ }^{51}$ Indians are using it as an enhancer of intellect. The seed oil is utilized to boost the memory. ${ }^{62}$ The oil lowers the concentrations of noradrenaline, 5-hydroxytryptamine and dopamine. In mentally challenged youngsters, it also increases IQ. Extract of methanol has an anti-inflammatory effect linked to the treatment of Alzheimer's disease. ${ }^{63}$

\subsubsection{Evolvulus alsinoides}

It is commonly found in India. Betain and $\beta$-sitosterol are active components of this plant, which work for stress, epilepsy, nerve retardants and insensitivity. ${ }^{64}$

\subsubsection{Petasites japonicus}

This plant is herbaceous. It is present in Hubei, Shanxi and Sichuan provinces of China. P. japonicus contains 19 sesquiterpenoids which are efficient as anti-allergic, antioxidants, anti-inflammatory and neuroprotective agents. Sesquiterpenoids encourage development of neurites. .5,66 $^{6}$

\subsubsection{Sida cordifolia}

This plant comprises the asparagine and ephedrine as its active ingredients. ${ }^{46}$ It is used to treat sciatica and Bell's palsy. The plant extract has powerful anti-inflammatory, analgesic and hypoglycemic effects. Plant roots and milk cure Parkinson's disease effectively. ${ }^{67}$

\subsubsection{Huperzia serrate}

In China, this herb is popularly referred as 'qianceng ta.' This herb is used for memory enhancement in Traditional Chinese Medicinal System (TCM). Its component, 'Lycopodium alkaloids', is a powerful and reversible AChE inhibitor. It is used to treat Alzheimer's disease by reducing free radicals in the brain. Amnesia produced by scopolamine is also overturned by it, indicating its efficacy in Alzheimer's disease for cognitive issues. ${ }^{68,69}$

\subsubsection{Tinospora cordifolia}

It is commonly known as guduchi. It improves memory and learning in animals. It increases acetylcholine levels and improves cognitive function. ${ }^{70}$

\subsubsection{Rhaponticum carthamoides}

This plant is widespread in China. It is used to treat hypertension, anepithymia and nervous prostration as a medication in China. Neurotrophic chemicals are commonly utilized for ecdysterone derived from the plant. ${ }^{71}$ The ecdysterone increases the neuronal damage caused by glutamate. ${ }^{59}$

\subsubsection{Urtica dioica}

It is commonly known as stinging nettle. It contains histamine, acetylcholine, proteins, and tryptamine 5-hydroxy. ${ }^{37}$ It is used to treat hay fever and other symptoms of allergies. It contains biological anti-inflammatory ingredients. It includes boron that improves the body's estrogen level, which is good for short-term memory. In Alzheimer's sufferers, it increases mood. ${ }^{72}$

\subsubsection{Acorus calamus $\mathrm{L}$.}

It is commonly known as sweet flag. Its hydroethanolic and ethanolic rhizomes extracts possess sedative and neuroprotective effects. ${ }^{49}$ The $a-$ and $\beta$-asarone is included in the product. This plant has memory-enhancing, anti-inflammatory, cytoprotective, antispasmodic, and antidiarrheal effects. ${ }^{73}$

\subsubsection{Galanthus nivalis $L$.}

Galanthamine is the principal component of galanthus nivalis. It contains isoquinoline alkaloid which is galanthamine. It is long acting AChEase inhibitor. It increases cholinergic nicotine neurotransmission by allosterically modifying the Alzheimer's disease-effective nicotine receptors. ${ }^{74}$

\subsubsection{Salix alba}

This plant has active ingredients such as salicine, populin, salicortin, fragiline, salicyl alcohol, tremulacine, saligenin, vanillin and salidroside. Salicin is an inhibitor for COX-1 and COX-2 and an anti-inflammatory substance by its activity to limit the production of prostaglandin. ${ }^{75,64}$

\subsubsection{Rheum glabricaule}

This plant contains $\mathrm{N}$-hexacosnic acid, daucosterol, palmitic acid, crystal 8-Me, glucopyranoside chrysophane, rhapontigenin, and citreorosein. These neuroprotective agents are utilised to treat Parkinson's disease. Moreover, the functioning of mitochondria with amyloid-beta (1-42) neurosis is protected by rhapontigenin which is a part of this plant. ${ }^{75}$

Table 1 gives the summary of above mentioned 35 ethnomedicinal plants.

Table 1 Summary of Ethnomedicinal plants to treat Neurodegenerative disorders

\begin{tabular}{|l|l|l|l|l|l|l|}
\hline $\begin{array}{l}\text { S. } \\
\text { No. }\end{array}$ & Scientific name & $\begin{array}{l}\text { Common } \\
\text { Name }\end{array}$ & Family Name & $\begin{array}{l}\text { Phytochemical Constit- } \\
\text { uents }\end{array}$ & Plant used For & Citation \\
\hline 1 & $\begin{array}{l}\text { Centella asi- } \\
\text { atica }\end{array}$ & Gotu kola & $\begin{array}{l}\text { Apiaceae/ Um- } \\
\text { belliferae }\end{array}$ & $\begin{array}{l}\text { Asiatic acid, iso- } \\
\text { thankunoside \& }\end{array}$ & Depression and epilepsy & 21,27 \\
\hline 2 & $\begin{array}{l}\text { Bacopa mon- } \\
\text { niera }\end{array}$ & Brahmisak & $\begin{array}{l}\text { Scrophularia- } \\
\text { ceae }\end{array}$ & $\begin{array}{l}\text { Bacopasaponins, } \\
\text { Stigmastanol, and } \\
\text { bacosides }\end{array}$ & $\begin{array}{l}\text { Boosts memory, De- } \\
\text { creases nervousness, }\end{array}$ & \begin{tabular}{l}
28,29 \\
\hline
\end{tabular}
\end{tabular}


Taimoor Hassan, et al.

\begin{tabular}{|c|c|c|c|c|c|c|}
\hline 3 & $\begin{array}{l}\text { Picrorhiza scro- } \\
\text { phulariiflora }\end{array}$ & $\begin{array}{l}\text { Hu Huang } \\
\text { Lian }\end{array}$ & $\begin{array}{l}\text { Scrophularia- } \\
\text { ceae }\end{array}$ & $\begin{array}{l}\text { phenolic glycosides } \\
\text { and terpenoids, }\end{array}$ & $\begin{array}{l}\text { Picrosides I and II } \\
\text { shows neurite, growth in } \\
\text { PC12D cells }\end{array}$ & 30 \\
\hline 4 & Ginkgo biloba & $\begin{array}{l}\text { Maiden hair } \\
\text { tree }\end{array}$ & Ginkgoaceae & $\begin{array}{l}\text { Quercetin, sesquiter- } \\
\text { penictrilactone, and } \\
\text { ginkgolides A, B, C, J }\end{array}$ & $\begin{array}{l}\text { Neuroprotective, Preven- } \\
\text { tion for AD. }\end{array}$ & 31 \\
\hline 5 & $\begin{array}{l}\text { Bertholettia } \\
\text { excels }\end{array}$ & Brazil Nuts & Lecythidaceae & Lecithin, & Alzheimer's disease & 32,33 \\
\hline 6 & $\begin{array}{l}\text { Cyperus rotun- } \\
\text { dus }\end{array}$ & Sedge & Cyperaceae & $\begin{array}{l}\text { essential oils such as } \\
\text { terpenes and pinene }\end{array}$ & $\begin{array}{l}\text { Improves spatial learn- } \\
\text { ing in Rats. }\end{array}$ & 34 \\
\hline 7 & $\begin{array}{l}\text { Lavandula offic- } \\
\text { inalis }\end{array}$ & Lavender & Lamiaceae & $\begin{array}{l}\text { Geraniol, ursolicacid, } \\
\text { linalool and camphor }\end{array}$ & $\begin{array}{l}\text { Decreases neurologic } \\
\text { deficit and ROS }\end{array}$ & 35,36 \\
\hline 8 & $\begin{array}{l}\text { Rosmarinus } \\
\text { officinalis }\end{array}$ & Rosemary & Lamiaceae & $\begin{array}{l}\text { ferulic acid, and eu- } \\
\text { genol }\end{array}$ & Alzheimer's disease & 31,37 \\
\hline 9 & $\begin{array}{l}\text { Hypericum } \\
\text { perforatum }\end{array}$ & Bulhsana & Hypericaceae & $\begin{array}{l}\text { Quercitrin,hayperciyn } \\
\text { and quercetin }\end{array}$ & Alzheimer disease & 38 \\
\hline 10 & $\begin{array}{l}\text { Glycyrrhiza } \\
\text { glabra }\end{array}$ & Liquorice & Fabaceae & $\begin{array}{l}\text { Glycyrrhizin and gly- } \\
\text { cyrrhetinic acid }\end{array}$ & Alzheimer's disease & 34,39 \\
\hline 11 & $\begin{array}{l}\text { Melissa officina- } \\
\text { lis L. }\end{array}$ & Lemon balm & Lamiaceae & luteolin-7-O- glucoside & Alzheimer's disease & 40 \\
\hline 12 & Curcuma longa & Turmeric & Zingiberaceae & Curcumin & Treats AD & 41 \\
\hline 13 & $\begin{array}{l}\text { Matricaria } \\
\text { recutita }\end{array}$ & Babonaj & Asteraceae & $\begin{array}{l}\text { a-bisobolol, chamazu- } \\
\text { lene, sesquiterpenes, }\end{array}$ & Insomnia and anxiety & 42 \\
\hline 14 & $\begin{array}{l}\text { Cassia obtusi- } \\
\text { folia }\end{array}$ & Senna & Fabaceae. & $\begin{array}{l}\text { Isorubrofusarin and } \\
\text { Rubrofusarin }\end{array}$ & $\begin{array}{l}\text { Reduces ROS genera- } \\
\text { tion }\end{array}$ & 43 \\
\hline 15 & Coffea Arabica & $\begin{array}{l}\text { Arabian } \\
\text { coffee }\end{array}$ & Rubiaceae & Caffeine & $\begin{array}{l}\text { Reverses motor deficit in } \\
\text { Parkinson's mice Model }\end{array}$ & 44 \\
\hline 16 & Panax ginseng & Ginseng & Araliaceae & Ginsenosides & $\begin{array}{l}\text { Neurodegenerative } \\
\text { disorders }\end{array}$ & 45,51 \\
\hline 17 & $\begin{array}{l}\text { Terminalia } \\
\text { chebula }\end{array}$ & Myrobalan & Combretaceae & $\begin{array}{l}\text { Chebulinic acid, cheb- } \\
\text { ulosides I and II }\end{array}$ & Enhances memory & 46,54 \\
\hline 18 & Clitoria ternatea & Butterfly-pea & Fabaceae & $\begin{array}{l}\text { sitosterol, kaemp- } \\
\text { ferol-3- rutinoside }\end{array}$ & $\begin{array}{l}\text { Treats } A D \text {, increases } \\
\text { memory }\end{array}$ & 47,48 \\
\hline 19 & $\begin{array}{l}\text { Commiphora } \\
\text { whighitti }\end{array}$ & $\begin{array}{l}\text { Guggul, } \\
\text { Mukul }\end{array}$ & Burseraceae & $\begin{array}{l}\text { Guggulipid and gug- } \\
\text { gulsterone }\end{array}$ & dementia preventer & 50 \\
\hline 20 & $\begin{array}{l}\text { Convolvulus } \\
\text { pluricaulis }\end{array}$ & Shahkpushpi & Convolvulaceae & $\begin{array}{l}\text { convolidine, confoline, } \\
\text { and kaemperfol }\end{array}$ & $\begin{array}{l}\text { memory loss and } \\
\text { syphilis }\end{array}$ & \begin{tabular}{|l}
51,52, \\
53
\end{tabular} \\
\hline 21 & $\begin{array}{l}\text { Withania som- } \\
\text { nifera }\end{array}$ & $\begin{array}{l}\text { Ashwagand- } \\
\text { ha }\end{array}$ & Solanaceae & $\begin{array}{l}\text { withasomniferin } \mathrm{A}, \mathrm{B}, \mathrm{C} \\
\text { and withanone }\end{array}$ & $\begin{array}{l}\text { Intellect and memory } \\
\text { enhancer }\end{array}$ & 54,59 \\
\hline 22 & $\begin{array}{l}\text { Commiphora } \\
\text { mukul }\end{array}$ & Gugal & Burseraceae, & $\begin{array}{l}\text { Terpenes, eugenol, } \\
\text { cuminic aldehyde, } \\
\text { sesquiterpenoids }\end{array}$ & $\begin{array}{l}\text { Decrease neuronal cho- } \\
\text { lesterol level }\end{array}$ & 55,60 \\
\hline 23 & Crocus sativus & Saffron & Iridaceae & $\begin{array}{l}\text { Gallic acids, safranal, } \\
\text { crocin, and } \alpha-\text { and } \beta \\
\text { carotenes }\end{array}$ & $\begin{array}{l}\text { Corrects impaired be- } \\
\text { havior and learning }\end{array}$ & 60,61 \\
\hline 24 & $\begin{array}{l}\text { Celastrus panic- } \\
\text { ulatus }\end{array}$ & Black-oil tree & Celastraceae & $\begin{array}{l}\text { Triacylglycerol and } \\
\text { esterified sterols }\end{array}$ & $\begin{array}{l}\text { Memory enhancer An- } \\
\text { ti-stress, }\end{array}$ & 62,63 \\
\hline 25 & $\begin{array}{l}\text { Evolvulus alsi- } \\
\text { noides }\end{array}$ & Sankha-holi & Convolvulaceae & betaine, $\beta$-sitosterol & Anti-stress & 64 \\
\hline 26 & $\begin{array}{l}\text { Petasites japon- } \\
\text { icas }\end{array}$ & $\begin{array}{l}\text { butterbur, } \\
\text { giant }\end{array}$ & Asteraceae & Sesquiterpenoids & Neuroprotection & 65,66 \\
\hline
\end{tabular}


Ethnomedicinal plants in the treatment of neurodegenerative diseases: a narrative review.

\begin{tabular}{|l|l|l|l|l|l|l|}
\hline 27 & Sida cordifolia & Beej band & Malvaceae & asparagine, ephedrine & $\begin{array}{l}\text { Sciatica, Parkinson's } \\
\text { disease }\end{array}$ & 46,67 \\
\hline 28 & $\begin{array}{l}\text { Huperzia ser- } \\
\text { rate }\end{array}$ & QianCeng, Ta & Lycopodiaceae & Lycopodium alkaloids & Alzheimer's disease & 68,69 \\
\hline 29 & $\begin{array}{l}\text { Tinospora cor- } \\
\text { difolia }\end{array}$ & Guduchi & $\begin{array}{l}\text { Menisperma- } \\
\text { ceae }\end{array}$ & alkaloids, terpenoids & $\begin{array}{l}\text { Improves cognitive } \\
\text { function }\end{array}$ & 70 \\
\hline 30 & $\begin{array}{l}\text { Rhaponticum } \\
\text { carthamoides }\end{array}$ & Maral root & Asteraceae & Ecdysterone & Treats Hypertension & 59,71 \\
\hline 31 & Urtica dioica & $\begin{array}{l}\text { Stinging } \\
\text { Nettle }\end{array}$ & Clusiaceae & $\begin{array}{l}\text { Acetylcholine, and 5- } \\
\text { hydroxytryptamine }\end{array}$ & Short term memory & 37,72 \\
\hline 32 & Acorus calamus & $\begin{array}{l}\text { Sweet } \\
\text { flag,Vacha }\end{array}$ & Araceae & $\begin{array}{l}\text { a-asarone and } \\
\text {-asarone }\end{array}$ & Memory enhancer & 49,73 \\
\hline 33 & $\begin{array}{l}\text { Galanthus } \\
\text { nivalis }\end{array}$ & Snowdrop & Amaryllidaceae & Galanthamine & Alzheimer's disease & 74 \\
\hline 34 & Salix alba & White willow & Salicaceae. & Salicin and saligenin & $\begin{array}{l}\text { Inhibits COX-1 and } \\
\text { COX-2 }\end{array}$ & 64,75 \\
\hline 35 & $\begin{array}{l}\text { Rheum glabri- } \\
\text { caule }\end{array}$ & Samuelsson & Polygonaceae & $\begin{array}{l}\text { n-hexacosnic acid and } \\
\text { citreorosein }\end{array}$ & $\begin{array}{l}\text { Mitochondrial protection } \\
\text { against amyloid-beta } \\
\text { neurotoxicity }\end{array}$ & 75 \\
\hline
\end{tabular}

\section{CONCLUSIONS \& FUTURE PROSPECTS}

Ethnomedicinal herbs have been utilized to cure neurogenerative illnesses for ages. In this study, thirty-five plants are studied, and it is determined that biochemicals derived from these plants are beneficial in the treatment of several neurodegenerative disorders. Depending on the plant or ailment, various parts of plant such as bark, root, stem, leaves, flowers, seeds, and fruits are utilized to extract biochemicals or administered intact to cure such disorders. In certain situations, though, the entire plant is used for this purpose. In today's era, the trend from allopathic medicines is changing gradually towards herbal medicines, as some allopathic medicine are considered to have serious side-effects. These natural plants are major stakeholders in this regard. There is so much to be discovered about the treatment of plethora of other neurodegenerative disorders such as progressive supranuclear palsy, multiple system atrophy, motor neuron disease etc. These biocompatible plant products are opening new horizon of research.

\section{REFERENCES}

1. Ayeni EA, Gong Y, Yuan H, Hu Y, Bai X, Liao $X$. Medicinal plants for anti-neurodegenerative diseases in West Africa. J Ethnopharmacol 2021 Aug;11(4):468-74. https://doi.org/10.1016/j. jep.2021.114468

2. Akram M, Nawaz A. Effects of medicinal plants on Alzheimer's disease and memory deficits. Neural Regen Res 2017 Apr;12(4):660-5. https:// doi.org/10.4103/1673-5374.205108

3. Roy A. Role of medicinal plants against Alzheimer's disease. Int $\mathrm{J}$ Complement Alt Med 2018;11(4):205-8. https://doi.org/10.15406/ ijcam.2018.11.00398
4. Husain GM, Mishra D, Singh PN, Rao KV. Ethnopharmacological review of native traditional medicinal plants for brain disorders. Pharmacog Rev 2007 Jan11(3):20-8.

5. Su Y, Wang Q, Wang C, Chan K, Sun Y, Kuang $\mathrm{H}$. The treatment of Alzheimer's disease using Chinese medicinal plants: from disease models to potential clinical applications. J Ethnopharmacol 2014 Mar 28;152(3):403-23. https://doi. org/10.1016/j.jep.2013.12.053

6. Kamran M, Kousar R, Ullah S, Khan S, Umer MF, Rashid HU, et al. Taxonomic distribution of medicinal plants for Alzheimer's Disease: a cue to novel drugs. J Prev Alzheimers Dis 2020 Jun;19(1);2017. https://doi.org/10.1155/2020/7603015

7. Auddy B, Ferreira M, Blasina F, Lafon L, Arredondo $F$, Dajas F, et al. Screening of antioxidant activity of three Indian medicinal plants, traditionally used for the management of neurodegenerative diseases. J Ethnopharmacol 2003 Feb 1;84(3):131-8. https://doi.org/10.1016/S0378-8741(02)00322-7

8. Prasansuklab A, Brimson JM, Tencomnao T. Potential Thai medicinal plants for neurodegenerative diseases: A review focusing on the anti-glutamate toxicity effect. J Tradit Complement Med 2020 May 1;10(3):301-8. https://doi.org/10.1016/j. jtcme.2020.03.003

9. Ratheesh G, Tian L, Venugopal JR, Ezhilarasu H, Sadiq A, Fan TP, et al. Role of medicinal plants in neurodegenerative diseases. Biomanufac Rev 2017 Dec;2(1):5-9. https://doi.org/10.1007/ s40898-017-0004-7

10. Hassan MA, Balasubramanian R, Masoud AD, Burkan ZE, Sughir A, Kumar RS. Role of medicinal plants in neurodegenerative diseases with special emphasis to Alzheimer's. Phytomedicine 2014;5(6):454-62. 
11. Pathak-Gandhi N, Vaidya AD. Management of Parkinson's disease in Ayurveda: medicinal plants and adjuvant measures. J Ethnopharmacol 2017 Feb 2;197(4):46-51. https://doi.org/10.1016/j. jep.2016.08.020

12. Pratap GK, Ashwini S, Manjula S. Alzheimer's disease: $A$ challenge in managing with certain medicinal plants-A review. Int J Pharm Sci Res 2017 Dec 1;12(8):4960-72.

13. Jivad N, Rabiei Z. A review study on medicinal plants used in the treatment of learning and memory impairments. Asian Pac J Trop Biomed 2014 Oct 1;4(10):780-9. https://doi.org/10.12980/ APJTB.4.2014APJTB-2014-0412

14. Roy A. Role of medicinal plants against Alzheimer's disease. Int $\mathrm{J}$ Complement Alt Med 2018;11(4):205-8. https://doi.org/10.15406/ ijcam.2018.11.00398

15. Lalotra S, Vaghela JS. Scientific reports of medicinal plants used for the prevention and treatment of neurodegenerative diseases. Pharm Biosci $\mathrm{J}$ 2019 Jan;19(3):15-25. https://doi.org/10.20510/ ukjpb/7/i1/179297

16. Mazo NA, Echeverria V, Cabezas R, Avila-Rodriguez M, Tarasov VV, Yarla NS, et al. Medicinal plants as protective strategies against Parkinson's disease. Curr Opin Mol Ther 2017 Aug $1 ; 23(83): 4180-8$. https://doi.org/10.2174/138161 2823666170316142803

17. Penido $\mathrm{AB}$, De Morais SM, Ribeiro AB, Alves DR, Rodrigues AL, Dos Santos, et al. Medicinal plants from northeastern Brazil against Alzheimer's disease. Evid Based Complement Alternat Med 2017 Feb;21(6):201-8. https://doi. org/10.1155/2017/1753673

18. Gaire BP. Herbal medicine in ischemic stroke: challenges and prospective. J Chi Integ Med 2018 Apr;24(4):243-6. https://doi.org/10.1007/ s11655-018-2828-2

19. Adewusi EA, Moodley N, Steenkamp V. Antioxidant and acetylcholinesterase inhibitory activity of selected southern African medicinal plants. S Afr J Bot 2011 Aug 1;77(3):638-44. https://doi. org/10.1016/j.sajb.2010.12.009

20. Sahoo S. A review of some medicinal plants used for nervous disorders. J Med Plant 2018;6(3):2204.

21. Khazaei H, Pesce M, Patruno A, Aneva IY, Farzaei $\mathrm{MH}$. Medicinal plants for diabetes associated neurodegenerative diseases: A systematic review of preclinical studies. Phythe Res 2021 Apr;35(4):1697-1718. https://doi.org/10.1002/ ptr.6903

22. Srikanth Y, Tamilanban T, Chitra V. Medicinal plants Targeting Alzheimer's disease-A Review. Res J Pharm Technol 2020;13(7):3454-8. https:// doi.org/10.5958/0974-360X.2020.00613.7

23. Prasansuklab A, Tencomnao T. Amyloidosis in Alzheimer's disease: the toxicity of amyloid beta $(A \beta)$, mechanisms of its accumulation and implications of medicinal plants for therapy. Evid Based Com- plement Alternat Med 2013 Oct;65(4):456-62. https://doi.org/10.1155/2013/413808

24. Sharma R. Medicinal plants Diversity in Bhilai city District Durg, Chhattisqarh, India. Int J Univers Pharm Life Sci 2016 Mar 1;7(3):342-9.

25. Sharma M, Sahu S, Khemani N, Kaur R. Ayurvedic medicinal plants as psychotherapeutic agents-A review. Int J Appl Biol Pharm 2013 Apr;9(2):214-8.

26. Luthra R, Roy A. Role of medicinal plants against neurodegenerative diseases. Curr Pharm Biotechnol 2021;21(2):219-25. https://doi.org/10.21 74/1389201022666210211123539

27. Taïwe GS, Kuete V. Neurotoxicity and neuroprotective effects of African medicinal plants. Tox Curr Afm plant 2014;43(2):423-44. https://doi. org/10.1016/B978-0-12-800018-2.00014-5

28. Lee HC, Hwang SG, Lee YC, Kim DG, Park YJ, Kim TE, et al. Screening of the acetylcholinesterase inhibitors from water extracts of the medicinal plants. J Physio Patho Kor Med 2002;16(2):215-9.

29. Panickar KS. Beneficial effects of herbs, spices and medicinal plants on the metabolic syndrome, brain and cognitive function. Cent Nerv Syst Agents Med Chem 2013 Mar 1;13(1):13-29. https://doi.org/10.2174/1871524911313010004

30. Currais A, Chiruta C, Goujon-Svrzic M, Costa G, Santos T, Batista MT, et al. Screening and identification of neuroprotective compounds relevant to Alzheimer's disease from medicinal plants of S. Tomé e Príncipe. J Ethnopharmacol 2014 Aug 8;155(1):830-40. https://doi.org/10.1016/j. jep.2014.06.046

31. Ranjan N, Kumari M. Acetylcholinesterase inhibition by medicinal plants: a review. Ann Plant Sci 2017;6(6):1640-4. https://doi.org/10.21746/ aps.2017.06.003

32. Farzaei MH, Shahpiri Z, Mehri MR, Bahramsoltani R, Rezaei M, Raeesdana A, et al. Medicinal plants in neurodegenerative diseases: perspective of traditional Persian medicine. Curr Drug Meta 2018 Apr 1;19(5):429-42. https://doi.org/10.2174/1389 200219666180305150256

33. Noysang $C$, Mahringer $A$, Zeino $M$, Saeed $M$, Luanratana $\mathrm{O}$, Fricker $\mathrm{G}$, et al. Cytotoxicity and inhibition of P-glycoprotein by selected medicinal plants from Thailand. J Ethnopharmacol 2014 Aug 8;155(1):633-41. https://doi.org/10.1016/j. jep.2014.06.001

34. Kaufmann D, Kaur Dogra A, Tahrani A, Herrmann F, Wink M. Extracts from traditional Chinese medicinal plants inhibit acetylcholinesterase, a known Alzheimer's disease target. Molecules 2016 Sep;21(9):1161-7. https://doi.org/10.3390/ molecules21091161

35. Khan A, Nazar H, Sabir SM, Irshad M, Awan SI, Abbas R, et al. Antioxidant activity and inhibitory effect of some commonly used medicinal plants against lipid per-oxidation in mice brain. Afr J Tradit Complement Altern Med 2014 Oct 27;11(5):8390. https://doi.org/10.4314/ajtcam.v11i5.14

36. Poddar S, Sarkar T, Choudhury S, Chatterjee S, 
Ghosh P. Indian traditional medicinal plants: A concise review. Int J Bot Study 2020;5(5):174-90.

37. Adams M, Gmünder F, Hamburger M. Plants traditionally used in age related brain disorders - A survey of ethnobotanical literature. J Ethnopharmacol 2007 Sep 25;113(3):363-81. https://doi. org/10.1016/j.jep.2007.07.016

38. Shakir T, Coulibaly AY, Kehoe PG. An exploration of the potential mechanisms and translational potential of five medicinal plants for applications in Alzheimer's disease. Am J Neurodegener Dis 2013;2(2):70-9.

39. Abdul BA, Vidhyavathi R, Magesh J, Vijayakumar M, Mustafa MM, Marikar FM. Synthesis and Development of BACE 1 Inhibitor for alzheimer's diseases from medicinal plants. Annu Res Rev Biol 2018 Aug;18:(1):110-8. https://doi.org/10.9734/ ARRB/2018/40571

40. Ven Murthy MR, K Ranjekar P, Ramassamy C, Deshpande M. Scientific basis for the use of Indian ayurvedic medicinal plants in the treatment of neurodegenerative disorders. Cent Nerv Syst Agents Med Chem 2010 Sep 1;10(3):238-46. https://doi.org/10.2174/1871524911006030238

41. Liu Y, Echeverria V, Xu Y. Medicinal Plants for Cardiovascular and Neurodegenerative Aging-Related Diseases: From Bench to Bedside. Front Pharmacol 2020 Sep 23;11(10):1566-74. https:// doi.org/10.3389/fphar.2020.585155

42. Orozco MF, Vázquez-Hernández A, Fenton-Navarro B. Active compounds of medicinal plants, mechanism for antioxidant and beneficial effects. Phyton 2019;88(1):436-51. https://doi. org/10.32604/phyton.2019.04525

43. Keshavarzi Z, Shakeri F, Barreto GE, Bibak B, Sathyapalan T, Sahebkar A. Medicinal plants in traumatic brain injury: Neuroprotective mechanisms revisited. Biofactors 2019 Jul;45(4):517-35. https://doi.org/10.1002/biof.1516

44. Solati K, Asadi-Samani M, Heidari-Soureshjani S. Medicinal plants effective on serotonin level: $A$ systematic review. J Pharm Res Int 2017;8(1):25568. https://doi.org/10.9734/JPRI/2017/36836

45. Manoharan S, Guillemin GJ, Abiramasundari RS, Essa MM, Akbar M, Akbar MD. The role of reactive oxygen species in the pathogenesis of Alzheimer's disease, Parkinson's disease, and Huntington's disease: a mini review. Oxid Med Cell Longev 2016; 2016:8590578. https://doi. org/10.1155/2016/8590578

46. Liu W, Ma H, DaSilva NA, Rose KN, Johnson SL, Zhang $L$, et al. Development of a neuroprotective potential algorithm for medicinal plants. Neurochem Int 2016 Nov 1;100(7):164-77. https://doi. org/10.1016/j.neuint.2016.09.014

47. Mukherjee PK, Kumar V, Houghton PJ. Screening of Indian medicinal plants for acetylcholinesterase inhibitory activity. Phyt Res Int J Dev Pharm Tox Plant 2007 Dec;21(12):1142-5. https://doi. org/10.1002/ptr.2224

48. Hassan M, Akhtar N, Riaz M, Khan SN, Shakeel
M, Tahir A. Characterization of phytopathogenetic strains of Pseudomonas and burkholderia and management by black seed oil. Pak Plant Pathol J 2020 Dec 31;32(2):213-23. https://doi. org/10.33866/phytopathol.030.02.0596

49. Palipoch $\mathrm{S}$. A review of oxidative stress in acute kidney injury: protective role of medicinal plants-derived antioxidants. Afr J Tradit Complement Altern Med 2013 Jun 18;10(4):88-93. https:// doi.org/10.4314/ajtcam.v10i4.15

50. Adewusi EA, Moodley N, Steenkamp V. Medicinal plants with cholinesterase inhibitory activity: a review. Afr J Biotechnol 2010;9(49):8257-76.

51. Bazzari AH, Bazzari FH. Medicinal plants for Alzheimer's disease: An updated review. Int J Herb Med 2018;6(2):81-5.

52. Bhattacharjee A, Chakraborty R, Sen S. Scientific Basis for Ayurvedic Medicinal Plants Against Alzheimer's Disease. Int J Herb Med 2020;54(9):55668. https://doi.org/10.1007/978-981-13-7248-3_5

53. Ríos JL, Onteniente M, Picazo D, Montesinos MC. Medicinal plants and natural products as potential sources for antiparkinson drugs. Planta Medica 2016 Jul;82(11/12):942-51. https://doi. org/10.1055/s-0042-107081

54. Ganesan K, Xu B. Ethnobotanical studies on folkloric medicinal plants in Nainamalai, Namakkal District, Tamil Nadu, India. Tre Phytochem Res 2017 Sep 1;1(3):153-68.

55. Kumar V. Potential medicinal plants for CNS disorders: an overview. Phytotherapy Research: J Med Plant Res 2006 Dec;20(12):1023-35. https:// doi.org/10.1002/ptr.1970

56. Aruoma OI, Bahorun T, Jen LS. Neuroprotection by bioactive components in medicinal and food plant extracts. Mutat Res Rev 2003 Nov 1;544(3):203-15. https://doi.org/10.1016/j.mrrev.2003.06.017

57. Michel J, Abd Rani NZ, Husain K. A review on the potential use of medicinal plants from Asteraceae and Lamiaceae plant family in cardiovascular diseases. Front Pharmacol 2020 Jun 5;11(9):852-61. https://doi.org/10.3389/fphar.2020.00852

58. Amoateng P, Quansah E, Karikari TK, Asase A, Osei-Safo D, Kukuia KK, et al. Medicinal plants used in the treatment of mental and neurological disorders in Ghana. Evid Based Complement Alternat Med 2018;31(1):189-94. https://doi. org/10.1155/2018/8590381

59. Chaturvedi HC, Jain M, Kidwai NR. Cloning of medicinal plants through tissue culture - a review. Evid Based Complement Alternat Med 2019;35(2):223-7.

60. Bei W, Peng W, Ma Y, Xu A, Qing NX. An anti-stroke herbal medicine reduces hydrogen peroxide-induced injury in NG108-15 cells. Neuro Lett 2004 Jun 17;363(3):262-5. https://doi. org/10.1016/j.neulet.2004.04.031

61. Delfan B, Bahmani M, Rafieian-Kopaei M, Delfan M, Saki K. A review study on ethnobotanical study of medicinal plants used in relief of toothache 
in Lorestan Province, Iran. Asian Pac J Trop Dis 2014 Sep 1;4(4):879-84. https://doi.org/10.1016/ S2222-1808(14)60751-9

62. Mikawlrawng K, Rani R, Kumar S, Bhardwaj AR, Prakash G. Anti-paralytic medicinal plants-review. J Tradit Complement Med 2018 Jan 1;8(1):4-10. https://doi.org/10.1016/j.jtcme.2017.02.001

63. Hassan W, Noreen H, Rehman S, Gul S, Amjad Kamal M, Paul Kamdem J, et al. Oxidative stress and antioxidant potential of one hundred medicinal plants. Curr Trends Med Chem 2017 May 1;17(12):1336-70. https://doi.org/10.2174/15680 26617666170102125648

64. Sedighi M, Bahmani M, Asgary S, Beyranvand F, Rafieian-Kopaei M. A review of plant-based compounds and medicinal plants effective on atherosclerosis. J Res Med Sci 2017;22(4):65770. https://doi.org/10.4103/1735-1995.202151

65. Ahmad M, Zafar M, Shahzadi N, Yaseen G, Murphey TM, Sultana S. Ethnobotanical importance of medicinal plants traded in herbal markets of Rawalpindi-Pakistan. Int J Herb Med 2018 Mar 1;11(12):78-89. https://doi.org/10.1016/j. hermed.2017.10.001

66. Kumaranb KR, Ahada MA, Rawab MS, Wahabb H, Hassana Z. Potential Malaysian medicinal plants for the treatment of Alzheimer's disease. Aus Herb Ins 2019;1 (4):222-7.

67. Akhtar MA, Raju R, Beattie KD, Bodkin F, Münch G. Medicinal plants of the Australian aboriginal Dharawal people exhibiting anti-inflammatory activity. Evid Based Complement Alternat Med 2016 Dec 27;45(2):201-6. https://doi. org/10.1155/2016/2935403

68. Adewusi EA, Steenkamp V. In vitro screening for acetylcholinesterase inhibition and antioxidant activity of medicinal plants from southern Africa. Asian Pac J Trop Biomed 2011 Oct 1;4(10):829-35. https://doi.org/10.1016/S1995-
7645(11)60203-4

69. Mahdy K, Shaker O, Wafay H, Nassar Y, Hassan $\mathrm{H}$, Hussein A. Effect of some medicinal plant extracts on the oxidative stress status in Alzheimer's disease induced in rats. Eur Rev Med Pharmacol Sci 2012 Jul 1;16(3):31-42.

70. Soni S, Kumar P, Verma VS, Sharma M. Significance of Indian medicinal plants used for treatment of dementia. Asian Res Pharm Sci 2014;4(4):202-5.

71. Malekmohammad K, Rafieian-Kopaei M, Sardari $\mathrm{S}$, Sewell RD. Effective antiviral medicinal plants and biological compounds against central nervous system infections: a mechanistic review. Curr Drug Discov Technol 2020 Aug 1;17(4):46983. https://doi.org/10.2174/15701638166661907 15114741

72. Bosch-Morell F, Villagrasa V, Ortega T, Acero N, Muñoz-Mingarro D, González-Rosende ME, et al. Medicinal plants and natural products as neuroprotective agents in age-related macular degeneration. Neural Regen Res 2020 Dec;15(12):220721. https://doi.org/10.4103/1673-5374.284978

73. Lee HC, Hwang SG, Kim DG, Ju SM, Youl HK, Kim WS, et al. Screening on monoamine oxidase $B$ inhibitor and antioxidant activity from the water extracts of medicinal plants. J Physio Patho in Kor Med 2002;16(3):458-63.

74. Avneet G, Pal SM, Siddhraj SS. A review on herbal Ayurvedic medicinal plants and its association with memory functions. Phytomedicine 2018;7(2):162-6.

75. Saki K, Bahmani M, Rafieian-Kopaei M. The effect of most important medicinal plants on two importnt psychiatric disorders (anxiety and depression)-a review. Asian Pac J Trop Med 2014 Sep 1;7(4):34-42. https://doi.org/10.1016/S19957645(14)60201-7

\section{CONFLICT OF INTEREST \\ Authors declare no conflict of interest. GRANT SUPPORT AND FINANCIAL DISCLOSURE None declared.}

\section{AUTHORS' CONTRIBUTION}

The following authors have made substantial contributions to the manuscript as under:
Conception or Design:
$\mathrm{TH}, \mathrm{XH}$
Acquisition, Analysis or Interpretation of Data:
$\mathrm{TH}, \mathrm{XH}, \mathrm{SS}, \mathrm{MH}, \mathrm{SN}, \mathrm{SS}$
Manuscript Writing \& Approval:
$\mathrm{TH}, \mathrm{XH}, \mathrm{SS}, \mathrm{MH}, \mathrm{SN}, \mathrm{SS}$

All the authors agree to be accountable for all aspects of the work in ensuring that questions related to the accuracy or integrity of any part of the work are appropriately investigated and resolved. 